\title{
Teknik Pendederan Abalon (Haliotis squamata) di Balai Perikanan Budidaya Laut (BPBL) Lombok, Provinsi Nusa Tenggara Barat
}

\section{The Separating Technique of Abalone (Haliotis squamata) at Marine Aquaculture Development Centre (MADC) Lombok, West Nusa Tenggara Province}

\author{
Ade Prasetyo Abdi ${ }^{1}$, Mohammad Faizal Ulkhaq ${ }^{1 *}$, Arif Habib Fasya ${ }^{1}$ \\ ${ }^{1}$ Program Studi Akuakultur, Program Studi Diluar Kampus Utama Universitas Airlangga Banyuwangi, Jl. \\ Wijaya Kusuma No. 113 Giri, Banyuwangi 68425, Jawa Timur. \\ *Email: m-faizalulkhaq@fpk.unair.ac.id
}

Submitted: 22 June 2021 Revised: 09 July 2021 Accepted: 22 July 2021 Publish: 31 July 2021

\begin{abstract}
Abstrak
Tujuan dari penelitian ini adalah untuk mengetahui teknik pendederan abalon (H. squamata) dan mengetahui permasalahan selama tahap pendederan di Balai Perikanan Budidaya Laut Lombok, Provinsi Nusa Tenggara Barat. Penelitian dilaksanakan pada tanggal 23 Desember 2019 sampai 21 Januari 2020. Metode yang digunakan yaitu metode deskriptif dengan pengambilan data meliputi data primer dan data sekunder. Data diambil dengan melakukan observasi, partisipasi aktif, wawancara, dan studi literatur. Teknik pendederan abalon (H. squamata) diawali dengan persiapan wadah, persiapan benih, penebaran benih, penyiponan, pemberian pakan, pengelolaan kualitas air, dan sampling pertumbuhan. Permasalahan yang ditemui selama tahap pendederan adalah ketersediaan pakan rumput laut yang tidak menentu.

Keyword : Abalon, H. squamata, teknik pendederan.
\end{abstract}

\begin{abstract}
The purpose of this research is to find out the abalone separating technique (H. squamata) and know the problems during separating at the Marine Aquaculture Development Centre, West Nusa Tenggara Province. Research are carried out on December 23, 2019 to January 21, 2020. The method used is descriptive method with data collection including primary data and secondary data. Data is taken by observing, active participation, interviewing, and literature review. Abalone separating techniques $(H$. squamata) begin with container preparation, seed preparation, seed stocking, seeding, feeding, water quality management, and growth sampling. Problems encountered during the separating stage are the uncertain availability of seaweed feed.
\end{abstract}

Keyword: Abalone, H. squamata, separating technique. 


\section{PENDAHULUAN}

Abalon merupakan gastropoda laut bercangkang satu (univalve) yang berasal dari genus Haliotis. Terdapat sekitar 100 spesies yang tersebar di perairan tropis hingga sub tropis seluruh dunia dan tujuh spesies diantaranya ditemukan di Indonesia (Hahn, 1989; Setyono, 2004). Abalon yang terdapat di Indonesia memiliki nilai ekonomis yang cukup tinggi. Nilai jual abalon berada pada kisaran harga Rp. 300.000 - 500.000,- per kilogram kering (Adimulya dkk., 2016; Tubalawony et al., 2016). Selain harga jual yang tinggi, permintaan pasar dunia terhadap abalon juga cenderung mengalami peningkatan setiap tahunnya yang didominasi oleh negaranegara di Benua Asia seperti Hongkong, Taiwan, dan Jepang (Department of Agriculture, Forestry and Fisheries, 2018).

Haliotis squamata merupakan salah satu spesies abalon tropis yang terdapat di Indonesia. Abalon $(H$. squamata) memiliki keunggulan jika dibandingkan spesies Haliotis lainnya. Keunggulan abalon ( $H$. squamata) yaitu memiliki daging yang lezat, harga jual yang tinggi dan memiliki daya tahan yang kuat terhadap perubahan lingkungan (Permana dkk., 2013; Marzuqi dkk., 2012). Oleh karena keunggulan yang dimilikinya tersebut maka H. Squamata berpotensi untuk dikembangkan.

Budidaya abalon (H. squamata) di Indonesia telah berhasil dilakukan di beberapa tempat salah satunya adalah Balai Perikanan Budidaya Laut (BPBL) Lombok. Teknologi budidaya yang telah berhasil dikuasai meliputi pembenihan, pendederan, dan pembesaran. Walaupun teknologi budidaya abalon telah berhasil dikuasai tetapi masih ditemui beberapa kendala pada tahap pendederan.

Kendala utama yang dialami pada tahap pendederan yaitu pertumbuhan yang relatif lambat dan ketersediaan pakan rumput laut yang masih bergantung pada musim (Elliott, 2000; Giri dkk., 2015). Tujuan dilakukan penelitian ini yaitu untuk mengetahui Teknik pendederan abalon dan permasalahan yang terjadi selama pendederan abalon ( $H$. squamata) di Balai Perikanan Budidaya Laut (BPBL) Lombok, Provinsi Nusa Tenggara Barat. 


\section{METODE}

\section{Waktu dan Tempat}

Penelitian dilaksanakan pada tanggal 23 Desember 2019 sampai 21 Januari 2020. Bertempat di Balai Perikanan Budidaya Laut (BPBL) Lombok yang terletak di Jalan Raya Sekotong, Desa Gili Genting, Kecamatan Sekotong Barat, Kabupaten Lombok Barat, Provinsi Nusa Tenggara barat.

\section{Metode Kerja}

Penelitian ini menggunakan metode deskriptif. Pelaksanaan metode deskriptif pada saat penelitian berlangsung yaitu mengamati dan mengikuti semua kegiatan yang berhubungan dengan Teknik pendederan abalon (H. squamata) di Balai Perikanan Budidaya Laut Lombok, Provinsi Nusa Tenggara barat.

\section{HASIL DAN PEMBAHASAN}

\section{Teknik Pendederan Abalon}

Teknik pendederan abalon di Balai Perikanan Budidaya Laut (BPBL) Lombok menggunakan metode keranjang apung yang dilakukan di dalam ruangan. Menurut Rusdi dkk. (2015) pendederan dengan metode keranjang apung merupakan metode terbaik jika dibandingkan metode tebar didasar bak. Teknik pendederan abalon dimulai dengan persiapan wadah, persiapan benih, penebaran benih, pemberian pakan, penyiponan, pengelolaan kualitas air, sampling pertumbuhan, hama dan penyakit, seta hambatan dan penanggulangan yang terjadi selama tahap pendederan abalon.

\section{Persiapan Wadah}

Wadah yang digunakan untuk pendederan yaitu bak fiber berukuran $2 \times 2 \times 0,75 \mathrm{~m}$. Persiapan bak diawali dengan pembersihan bak menggunakan sikat. Menurut Andriyanto dan Listyanto (2010) pembersihan bak bertujuan untuk menghilangkan kotoran dan kerak yang melekat pada dinding dan dasar bak. Setelah itu dilakukan sterilisasi menggunakan larutan kaporit dengan dosis 200 ppm kemudian diaerasi kuat selama 24 jam. Hal ini sesuai dengan International des Epizootiez (2003) bahwa desinfeksi pada wadah dan peralatan dilakukan menggunakan kaporit dengan dosis minimum 200 ppm lalu diaerasi kuat selama 24-48 jam.

\section{Persiapan benih}

Benih yang akan digunakan untuk tahap pendederan adalah benih 
berusia 60 hari sejak menetas yang berasal dari hatchery abalon Balai Perikanan Budidaya Laut (BPBL) Lombok. Menurut Permana dkk. (2017) pada hari ke 60 dilakukan pemanenan benih abalon dari rearing plate. Benih kemudian diseleksi untuk memilih benih yang layak masuk tahap pendederan. Kriteria benih yang layak yaitu ukuran inimal $1 \mathrm{~cm}$, cangkang utuh, melekat kuat pada rearing plate, dan akan menghindar saat akan diambil menggunakan spatula. Hal ini sesuai dengan pernyataan Susanto dkk. (2013) bahwa benih abalon yang baik ditandai dengan adanya gerakan jika terkena rangsangan, melekat kuat pada substrat, daging dan cangkang dalam keadaan utuh.

\section{Penebaran Benih}

Penebaran benih dilakukan dengan memindahkan benih yang telah dipanen ke dalam keranjang apung. Padat tebar tiap keranjang berukuran 40x20x10 cm sebanyak 200-250 ekor. Menurut Susanto dkk. (2012) padat tebar benih sebanyak 125-250 ekor setiap satu keranjang berukuran $35 \times 25 \times 8 \quad \mathrm{~cm}$ memberikan laju pertumbuhan lebih baik jika dibandingkan padat tebar lebih tinggi.

\section{Pemberian Pakan}

Abalon diberikan pakan alami berupa makroalga dari jenis Gracillaria sp. selama tahap pendederan berlangsung yang diperoleh dari perairan laut daerah sekotong atau membeli dari pembudidaya. Gracillaria sp. dipilih karena memiliki kandungan nutrisi yang sesuai dengan kebutuhan abalon. Viera et al. (2014) melaporkan bahwa Gracillaria sp. memiliki kandungan protein, lemak, dan karbohidrat masing-masing senilai 18,8 ; 4,3; dan 41,8 \%. Pemberian pakan diawali dengan membersihkan pakan menggunakan air mengalir. Menurut Loekman dkk. (2017) pencucian pakan bertujuan untuk menghilangkan kotoran yang masih menempel pada pakan. Setelah bersih pakan dapat langsung diberikan pada abalone secara ad libitum dengan frekuensi dua hari sekali atau jika pakan terlihat sudah habis.

\section{Penyiponan}

Penyiponan bak pendederan abalon dilakukan setiap hari untuk mengeluarkan sisa-sisa pencernaan abalone berupa feses yang mengendap di dasar bak. Keberadaan feses pada bak pendederan dapat menyebabkan peningkatan akumulasi ammonia dalam 
air apabila tidak dibersihkan (Cheng et al., 2004). Kadar ammonia yang melebihi batas toleransi $(>0,16 \mathrm{mg} / \mathrm{l})$ dapat menjadi faktor penghambat pertumbuhan dan mengganggu kesehatan abalon (Harris et al., 1998; Naylor et al., 2011).

\section{Pengelolaan Kualitas Air}

Kualitas air selama pendederan dipertahankan agar supaya tetap optimal dengan menerapkan sistem flowthrough. Kelebihan system ini yaitu masuknya air baru akan membawa oksigen terlarut sedangkan kandungan karbon dioksida, ammonia dan feses yang terlarut dalam air akan ikut keluar bersamaan dengan aliran air keluar (Tucker and Hargreaves, 2008). Pengecekan kualitas air dilakukan seminggu sekali dengan parameter antara lain suhu, salinitas, DO, ammonia, dan $\mathrm{pH}$. Hasil pengukuran kualitas air selama pendederan berlangsung dapat dilihat pada table 1 .

\section{Pertumbuhan Benih}

Parameter pertumbuhan yang diamati selama pendederan abalon meliputi berat, panjang cangkang dan lebar cangkang yang diperoleh melalui kegiatan sampling setiap minggu sekali.. Menurut Susanto dkk. (2010) Pertumbuhan benih abalon dapat diketahui dengan mengukur pertambahan panjang cangkang, lebar cangkang, dan berat badan benih. Pertumbuhan benih abalon selama pendederan dapat dilihat pada gambar 1 dan 2 .

Tabel 1. Kualitas air bak pendederan abalon

\begin{tabular}{|c|c|c|c|}
\hline Parameter & Satuan & Hasil & Kisaran Optimum \\
\hline Suhu & ${ }^{0} \mathrm{C}$ & $28-30$ & $\begin{array}{c}24-30 \\
\text { (Chen } \text { et al., 1984) }\end{array}$ \\
\hline Salinitas & ppt & $30-33$ & $\begin{array}{c}30-36 \\
(\text { Amin dkk., 2016) }\end{array}$ \\
\hline DO & $\mathrm{mg} / \mathrm{l}$ & $7,2-7,7$ & $\begin{array}{c}6,5-8 \\
\text { (Leighton, 2008) }\end{array}$ \\
\hline Ammonia & $\mathrm{mg} / \mathrm{l}$ & $0,02-0,08$ & $\begin{array}{c}<0,16 \\
\text { (Harris et al., 1998) }\end{array}$ \\
\hline $\mathrm{pH}$ & - & $7,4-7,8$ & $\begin{array}{c}>7 \\
(\text { Naylor } \text { et al., 2011) }\end{array}$ \\
\hline
\end{tabular}




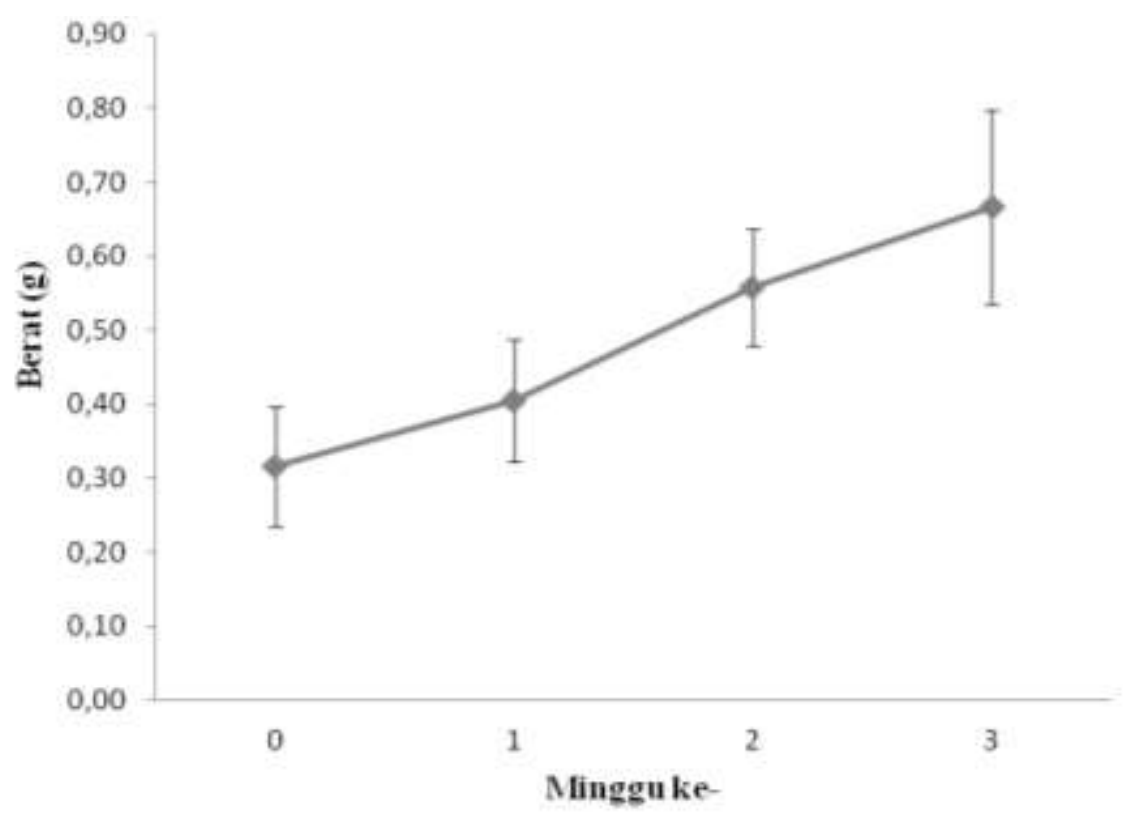

Gambar 1. Pertumbuhan berat abalon (H. squamata)

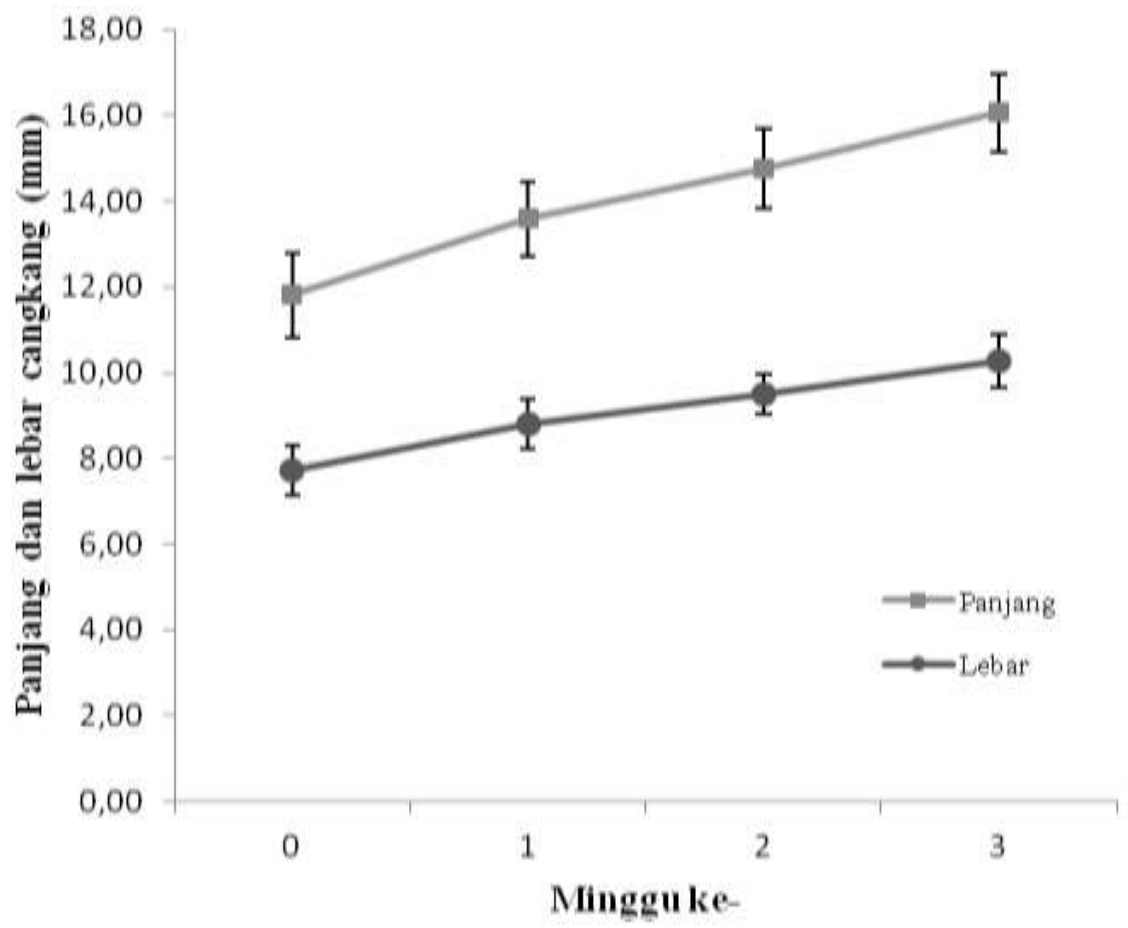

Gambar 2. Pertumbuhan panjang dan lebar cangkang abalon (H. squamata) 
Terlihat pola grafik (Gambar 1 dan 2) yang terus mengalami peningkatan seiring dengan bertambahnya umur pemeliharaan benih abalon. Rata-rata peningkatan berat, panjang dan lebar cangkang setiap minggu masing-masing sebesar $0,11 \mathrm{~g}, 1,4 \mathrm{~mm}$, dan $0,8 \mathrm{~mm}$. Benih abalon dapat tumbuh dengan peningkatan berat, panjang dan lebar cangkang masing-masing berada pada kisaran 0,06-0,09 g, 0,6-1,1 mm, dan 0,3-0,4 mm setiap minggunya (Susanto dkk., 2010; Rusdi., 2015). Hal ini mengindikasikan bahwa benih abalon di Balai Perikanan Budidaya Laut Lombok mengalami pertumbuhan yang relatif lebih tinggi. Adapun faktor yang sangat berpengaruh dalam menunjang pertumbuhan benih abalon diantaranya faktor genetik, padat tebar, kualitas air, dan ketersediaan pakan berkualitas serta berkelanjutan (Elliot, 2000; Susanto dkk., 2012; Giri dkk., 2015).

\section{Hama dan Penyakit}

Hama yang ditemukan selama pendederan abalon yaitu kepiting dan siput. Menurut Octaviany (2007) kepiting, siput liar, gurita dan bintang laut merupakan hama bagi abalon. Keberadaan hama selama tahap pendederan akan menyebabkan lambatnya pertumbuhan hingga kematian benih. Kepiting akan bertindak sebagai predator yang memangsa benih abalon, sedangkan siput liar menjadi kompetitor dalam mendapatkan oksigen, makanan, dan tempat penempelan sehingga akan menghambat pertumbuhan abalon (Andriyanto dan Listyanto, 2010).

Selama pendederan tidak ditemui adanya penyakit pada abalon. Hal ini mengindikasikan bahwa abalon yang dipelihara dalam kondisi sehat. Kesehatan abalon dipengaruhi oleh beberapa faktor diantaranya kualitas air yang baik dan tidak adanya patogen pada bak pendederan abalon. Namun, menurut Dang et al., (2012) resiko terserang penyakit pada abalon akan semakin meningkat apabila kualitas air tidak dijaga dengan baik. Adapun penyakit yang kemungkinan dapat menyerang abalon yaitu Mass Mortality Diseases disebabkan oleh bakteri Vibrio sp. dan Pasteurella sp. (Kua et al., 2011).

\section{Hambatan dan Penanggulangan}

Hambatan yang dialami selama pendederan yaitu ketersediaan pakan Gracillaria sp. yang tidak menentu karena keberadaannya masih 
dipengaruhi oleh musim. Upaya penanggulangan yang dapat dilakukan dengan pemberian pakan buatan. Pakan bisa diproduksi setiap waktu dan dapat disimpan dalam kurun waktu tertentu sehingga dapat menjadi alternatif apabila ketersediaan pakan Gracillaria sp. sedang menurun (Susanto dkk., 2010).

\section{KESIMPULAN DAN SARAN}

Teknik pendederan abalon $(H$. squamata) di Balai Perikanan Budidaya Laut (BPBL) Lombok diawali dengan persiapan wadah, persiapan benih, penebaran benih, penyiponan, pemberian pakan, pengelolaan kualitas air, sampling pertumbuhan. Kendala utama ketersediaan pakan Gracillaria sp. masih bergantung pada musim. Untuk menanggulanginya maka perlu dilakukan pemberian pakan Gracillaria sp. yang dikombinasi dengan pakan buatan.

\section{DAFTAR PUSTAKA}

Adimulya, R.A., O. L. Ola, dan A. Bafadal. 2016. Analisis Pendapatan dan Prospek Agribisnis Abalon (Haliotis asinina) di Kabupaten Konawe dan Kota Kendari. Jurnal Sosio Agribisnis, 1 (1): 85-98.

Amin, A., Yusnaini, I. J. Effendy. 2016. Pengaruh Salinitas terhadap Perkembangan Metamorfosis dan Pertumbuhan Larva Abalon Hybrid Sampai Juvenil Muda Umur 35 Hari. Media Akuatika, 1 (4): 197-206.
Andriyanto, S. dan N. Listyanto. 2010. Manajemen Pemeliharaan Induk Abalon (Haliotis asinina) Hasil Tangkapan Dari Alam. Media Akuakultur, 5 (2): 162-168.

Chen H. C. 1984. Recent innovations in Cultivation of Edible Molluscs in Taiwan with Special Reference to The Small Abalone Haliotis diversicolor and The Hard Clam Metretrix lusoria. Aquaculture, 39: 11-27.

Cheng, W., I. Hsiao, and J. Chen. 2004. Effect of ammonia on the immune Response of Taiwan Abalone Haliotis diversicolor supertexta and Its Susceptibility to Vibrio parahaemolyticus. Fish and Shellfish Immunology, 17: 193-202.

Dang, V. T., Speck P., and Benkendorff K. 2012. Influence of Elevated Temperatures on The Immune Respone of Abalone, Haliotis rubra. Journal Fish and Shellfish Immunology, 32 : 732-740.

Department of Agriculture, Forestry and Fisheries. 2018. Abalone Feasibility Study Final Report. Republic of South Africa: Department of Agriculture, Forestry and Fisheries. pp. 37.

Elliott, N. G. 2000. Genetic Improvement Programmes in Abalone: What Is The Future?. Aquaculture Research, 31 (1): 51-59.

Giri, N. A., M. Marzuqi, N. W. W. Astuti, W. Andriyanto, I. Rusdi, dan R. Andamari. 2015. Evaluasi Bahan Baku Pakan dan Pengembangan Pakan Buatan Untuk Budidaya Pembesaran Abalon (Haliotis squamata). Jurnal Riset Akuakultur, 10 (3): 379-388.

Hahn, K. O. 1989. Handbook of Culture Abalone and Other Marine Gastropods. Boca Raton, Florida: CRC Press, pp. 312.

Harris, J.O., G. B. Maguire and S. M. Hindrum. 1998. Effect of Ammonia on The Growth Rate and Oxygen Consumption of Juvenile Greenlip Abalone, Haliotis laevigata Donovan. Aquaculture, 160: 259-272.

Kua, B. C., R. Ramly, M. N. Devakie, D. Groman and F. C. J. Berthe. 2011. 
Investigating A Mortality in Hatchery Cultured Tropical Abalone, Haliotis asinina Linnaeus, 1758 in Malaysia. Disease in Asian Aquaculture VII. Asian Fisheries Society, 7 : 103-110.

Leighton, P. 2008. Abalone Hatchery Manual. Dublin, Ireland: Aquaculture Technical Section, Aquaculture Development Division, Bord Iascaigh Mhara. 88 pp.

Loekman, A. N., A. Manan, M. Arie dan Prayogo. 2017. Teknik Pendederan Kerang Abalon (Haliotis squamata) di Balai Besar Penelitian dan Pengembangan Budidaya Laut GondolBali. Journal of Aquaculture and Fish Health, 7 (2): 78-83.

Marzuqi, M., I. Rusdi, dan B. Susanto. 2012. Aplikasi Pakan Buatan Pada Pemeliharaan Benih Abalon (Haliotis squamata). Jurnal Riset Akuakultur, 7 (2): 237-245.

Naylor, M. A., H. Kaiser and C. L. W. Jones. 2011. Water Quality in A Serial-Use Raceway and Its Effect on The Growth of South African abalone, Haliotis midae Linnaeus, 1758. Aquaculture Research, 42: 918-930.

Octaviany, M. J. 2007. Beberapa Catatan Tentang Aspek Biologi dan Perikanan Abalon. Oseana, 32 (4) : 39-47.

Office International des Epizooties. 2003. Manual Diagnostic Test for Aquatic Animals: Methods for Disinfection of Aquaculture Establishment. France: Rue de Prony, 1-358 pp.

Permana, G. N., I. Rusdi, B. Susanto, F. H. Khotimah, dan H. Setyabudi. 2013. Karakterisasi Genetik Hibrida Abalon (Haliotis squamata dan Haliotis asinina). Prosiding Forum Inovasi Teknologi Akuakultur 2013, hal 533-53.

Permana, G. N., F. H. Khotimah, B. Susanto, I. Rusdi, dan Haryanti. 2017. Keragaan Pertumbuhan dan Reproduksi Abalon Haliotis squamata Reeve (1846) Turunan Ketiga. Jurnal Riset Akuakultur, 12 (3) : 197-202.

Rusdi, I., B. Susanto, F. H. Khotimah, dan I. G. N. Permana. 2015. Pertumbuhan dan
Sintasan Yuwana Abalon (Haliotis squamata) Pada Pendederan di Bak Dengan Berbagai Metode. Prosiding Forum Inovasi Teknologi Akuakultur 2015, hal 1081-1089.

Setyono, D. E. D. 2004. Abalone (Haliotis asinina L): 1. A Prospective Species for Aquaculture in Indonesia. Oseana, 29 (2): $25-30$.

Susanto, B., I. Rusdi, S. Ismi, dan R. Rahmawati. 2010. Pemeliharaan Yuwana Abalon (Haliotis squamata) Turunan F-1 Secara Terkontrol Dengan Jenis Pakan Berbeda. Jurnal Riset Akuakultur, 5 (2): 199-209.

Susanto, B., I. Rusdi, dan I. N. A. Giri. 2012. Optimalisasi Pemeliharaan Yuwana Abalon (H. squamata) Dengan Kepadatan dan Jenis Pakan Yang Berbeda. Jurnal Riset Akuakultur, 7 (1) : 21-31.

Susanto, B., I. Rusdi, dan F. H. Khotimah. 2013. Uji Kaji Teknik Pendederan Dan Pembesaran Abalon (Haliotis squamata) di Masyarakat. Prosiding Forum Inovasi Teknologi Akuakultur 2013, hal. 239247.

Tubalawony, J., F. Wattimena, J. Latuihamallo, J. Matakupan. 2016. Marketing Study of Dry Abalone (Haliotis asinina Linnaeus, 1758) in District of South East Maluku. 2nd International Symposium on Aquatic Products Processing and Health Isapprosh 2015. Aquatic Procedia, 7: 146-153.

Tucker, S. C. and J. A. Hargreaves. 2008. Environmental Best Management Practices for Aquaculture. Iowa, UA: Blackwell Publishing Professional. 594 pp.

Viera,M. P., G. C. Vicose, H. FernandezPalacios, and M. Izquierdo. 2014. GrowOut Culture of Abalone Haliotis tuberculata coccinea Reeve, Fed Landbased IMTA Produced Macroalgae, in a Combined Fish/Abalone Offshore Mariculture System: Effect of Stocking Density. Aquaculture Research, 47 (1): $1-11$. 